\title{
PEPOP 2.0: new approaches to mimic non-continuous epitopes
}

\author{
Vincent Demolombe ${ }^{1}$, Alexandre G. de Brevern²,3,4,5 ${ }^{2}$ Liza Felicori ${ }^{6}$, Christophe NGuyen", \\ Ricardo Andrez Machado de Avila ${ }^{8}$, Lionel Valera ${ }^{9}$, Bénédicte Jardin-Watelet ${ }^{9}$, Géraldine Lavigne ${ }^{10}$, \\ Aurélien Lebreton ${ }^{11}$, Franck Molina ${ }^{7}$ and Violaine Moreau ${ }^{12^{*}}$ (D)
}

\begin{abstract}
Background: Bioinformatics methods are helpful to identify new molecules for diagnostic or therapeutic applications. For example, the use of peptides capable of mimicking binding sites has several benefits in replacing a protein which is difficult to produce, or toxic. Using peptides is less expensive. Peptides are easier to manipulate, and can be used as drugs. Continuous epitopes predicted by bioinformatics tools are commonly used and these sequential epitopes are used as is in further experiments. Numerous discontinuous epitope predictors have been developed but only two bioinformatics tools have been proposed so far to predict peptide sequences: Superficial and PEPOP 2.0. PEPOP 2.0 can generate series of peptide sequences that can replace continuous or discontinuous epitopes in their interaction with their cognate antibody.
\end{abstract}

Results: We have developed an improved version of PEPOP (PEPOP 2.0) dedicated to answer to experimentalists' need for a tool able to handle proteins and to turn them into peptides. The PEPOP 2.0 web site has been reorganized by peptide prediction category and is therefore better formulated to experimental designs. Since the first version of PEPOP, 32 new methods of peptide design were developed. In total, PEPOP 2.0 proposes 35 methods in which 34 deal specifically with discontinuous epitopes, the most represented epitope type in nature.

Conclusion: Through the presentation of its user-friendly, well-structured new web site conceived in close proximity to experimentalists, we report original methods that show how PEPOP 2.0 can assist biologists in dealing with discontinuous epitopes.

Keywords: Peptide design, Discontinuous and continuous epitope, B-cell epitope, Ag-ab interaction, IPP, Protein surface, Structural bioinformatics, Immunogenicity, Antigenicity, Molecular mimicry

\section{Background}

The antigen-antibody (Ag-Ab) interaction is the basis of the immune system, and the $\mathrm{Ab}$ is a valuable tool in various biomedical applications, including diagnosis and therapy research $[1,2]$. The Ab plays a key role in two phenomena: immunogenicity and antigenicity. Immunogenicity is the ability of a molecule to induce an immune response in the host, yielding Abs. Antigenicity is the ability of a molecule to bind specifically to an Ab. Abs are known to exhibit highly specific binding, though off-target binding can occur [3]. The paratope of the $\mathrm{Ab}$

\footnotetext{
* Correspondence: violaine.moreau@cbs.cnrs.fr

${ }^{12}$ Centre de Biochimie Structurale (CBS), INSERM, CNRS, Univ Montpellier, 29, route de Navacelles, 34090 Montpellier, France

Full list of author information is available at the end of the article
}

interacts with the epitope of the protein Ag. An epitope can be continuous or discontinuous, linear or conformational [4-6]. A continuous, linear, or sequential, epitope is a fragment of the protein sequence. A discontinuous epitope is composed of several small fragments that are scattered in the protein sequence, but are close when the protein is structured. A conformational epitope has to be correctly structured to be recognized by the $\mathrm{Ab}$ and is often discontinuous, although it can also be continuous, for example, in the case of a constraint mimotope.

Epitope prediction tools have been developed for two major reasons $[7,8]$. First, to identify in the protein fragments which are expected to be more efficient and specific than the rest of the protein in eliciting anti-protein Abs by immunization in a host. Second, to identify

(c) The Author(s). 2019 Open Access This article is distributed under the terms of the Creative Commons Attribution 4.0 International License (http://creativecommons.org/licenses/by/4.0/), which permits unrestricted use, distribution, and reproduction in any medium, provided you give appropriate credit to the original author(s) and the source, provide a link to the Creative Commons license, and indicate if changes were made. The Creative Commons Public Domain Dedication waiver (http://creativecommons.org/publicdomain/zero/1.0/) applies to the data made available in this article, unless otherwise stated. 
epitopes recognized by an existing Ab. These tools hope to overcome the difficulties in experimentally mapping epitopes on proteins $[9,10]$, as the most accurate method is the 3D structural identification of the Ag-Ab complex by X-ray crystallography, which is a time-consuming and laborious procedure.

The first epitope prediction tools predicted continuous epitopes from the protein sequence using propensity scales based on different physico-chemical properties [11] such as hydrophilicity [12], flexibility [13], $\beta$-turns [14], surface accessibility [15], or antigenicity [16]. Despite attempted improvements in the methodology $[17,18]$, among them the combination of properties [19], Blythe \& Flower showed that the predictions are not better than chance [20]. It was supposed that because most of the epitopes are discontinuous [21, 22], the tools did not sufficiently take into account this criterion. The epitope prediction tools should consider structural information and target the identification of discontinuous epitopes. It is only rather belatedly that researchers have taken an interest in considering the 3D structure of the protein [23-25]. New epitope prediction tools are regularly developed [26-29].

Important research developments in this field do not concern real "ab initio" epitope prediction tools but fast and efficient methods dedicated to the complex task of dealing with discontinuous epitopes (either in helping to map them or in proposing immunogenic peptide sequences). These new bioinformatics methods could help in dealing with the discovery of new molecules, such as biomarkers or therapeutics, resulting from the highthroughput technologies like proteomics [30, 31]. They could provide solutions to characterize these new molecules by developing probes to capture them, by mapping epitopes, identifying interaction sites, finding peptide surrogates, etc. Despite the interest in using prediction tools, in the end, the experimentalist will use peptides, either for immunization or to replace the protein in the interaction with the $\mathrm{Ab}$ [32]. But, compared to continuous epitopes which are synthesized as is, the prediction of peptides mimicking discontinuous epitopes is more complicated as a correct arrangement between the elements composing the epitope has to be found in order to build the peptide (see Additional file 1). Moreover, it is known that the recognition of the Ab can be very sensitive to the sequence: only one mutation can alter the interaction (Duarte $\mathrm{C}$ et al., A mimic of a discontinuous epitope from $\mathrm{AaH}$ II identified by combining wet and dry experiments: a new experimental methodology to localize discontinuous epitopes, in preparation). Thus, using the relevant sequence is crucial. To date, only two bioinformatics tools propose the prediction of peptide sequences using 3D information: Superficial [33] and PEPOP [34]. Superficial predicts continuous and discontinuous peptides representing a potential epitope. The tool determines accessible protein fragments in a defined region on the protein and gathers them in a peptide, adding residues to link the fragments between them. PEPOP 2.0 is an antigenic and immunogenic peptide prediction tool. The first version of PEPOP proposed three different methods to design peptides and we showed that they can be used to generate anti-protein Abs [34] or to map epitopes [35]. In our new research, we have focused on novel methods that predict peptides representative of discontinuous epitopes and we have benchmarked them (Demolombe V et al., Benchmarking the PEPOP methods for mimicking discontinuous epitopes, submitted).

In this article, we present innovative methods, through different studies, which can bring solutions to biologists' difficulties with discontinuous epitopes using PEPOP 2.0 and its new web site conceived in close proximity to experimentalists. Peptides predicted by PEPOP 2.0 have been used as immunogens to prepare anti-protein Abs using one peptide targeting one specific region. They have also been used in pairs to target two distinct regions on the protein, allowing the capture of the Ag. Peptides predicted by PEPOP 2.0 have then been used as Ags either to experimentally map an epitope or to find an inhibitor of an Ab-Ag interaction. We show the interest of using peptides that can represent the cognate protein. The ensemble of these improvements has been implemented in the improved web-site. PEPOP 2.0 is available at https://www.sys2diag.cnrs.fr/index.php?page= pepop.

\section{Results}

\section{Description of PEPOP 2.0}

PEPOP 2.0 [34] is a tool dedicated to the prediction of peptides able to replace a protein in its interaction with an Ab. PEPOP 2.0 computes different combinations between surface accessible segments or aa using 34 different algorithms (Experimental procedures, Table 1 and (Demolombe V et al., Benchmarking the PEPOP methods for mimicking discontinuous epitopes, submitted)) to finally propose one or a list of linear peptides mimicking discontinuous epitopes. A comparison of known epitopes [36] with PEPOP predictions is reported in Additional file 2: Table S1 and shows that PEPOP predictions can include on average $84 \%$ of the epitope aa.

PEPOP 2.0 is available in an improved new version of the web site (Fig. 1). The web interface is composed of 3 sections that can correspond to different ways to use PEPOP 2.0 in experimental projects. Below are four examples using PEPOP 2.0 to predict peptides and use them in experiments. Each user is free to imagine other ways to use these "discontinuous" peptides.

The sections 'One Specific Peptide Design' and 'Paired Peptide Design' are dedicated to the prediction of 
Table 1 PEPOP 2.0 methods and their main characteristics

\begin{tabular}{|c|c|c|c|c|c|c|}
\hline Category & Sub category & Name & Full name & Composing elements & Characteristic & $\begin{array}{l}\text { Epitope type } \\
\text { mimetic }\end{array}$ \\
\hline & Sequential & FPS & $\begin{array}{l}\text { Flanking Protein } \\
\text { Sequence }\end{array}$ & protein sequence & $\begin{array}{l}\text { Extension of a segment } \\
\text { with the protein sequence }\end{array}$ & continuous \\
\hline \multirow[t]{20}{*}{$\begin{array}{l}\text { Nearest } \\
\text { Neigbors }\end{array}$} & \multirow[t]{6}{*}{ Prime methods } & NN & Nearest Neighbors & $\begin{array}{l}\text { segments in the natural } \\
\text { orientation }\end{array}$ & $\begin{array}{l}\text { Sequentially concatenation } \\
\text { of NN segments }\end{array}$ & discontinuous \\
\hline & & uNN & upset NN & $\begin{array}{l}\text { segments in the natural or } \\
\text { reverse orientation }\end{array}$ & $\begin{array}{l}\text { Sequentially concatenation } \\
\text { of NN segments }\end{array}$ & \\
\hline & & FNN & Flanking NN & $\begin{array}{l}\text { segments in the natural } \\
\text { orientation }\end{array}$ & $\begin{array}{l}\text { Concatenation in turn C- } \\
\text { and N-terminally of NN } \\
\text { segments }\end{array}$ & \\
\hline & & ONN & Optimized NN & $\begin{array}{l}\text { segments in the natural } \\
\text { orientation }\end{array}$ & $\begin{array}{l}\text { Shortest path between the } \\
\text { segments of NN method }\end{array}$ & \\
\hline & & OFN & Optimized Flanking NN & $\begin{array}{l}\text { segments in the natural } \\
\text { orientation }\end{array}$ & $\begin{array}{l}\text { Shortest path between the } \\
\text { segments of FNN peptides }\end{array}$ & \\
\hline & & OPP & $\begin{array}{l}\text { Optimized Patched } \\
\text { segments Path }\end{array}$ & $\begin{array}{l}\text { segments in the natural } \\
\text { orientation }\end{array}$ & $\begin{array}{l}\text { Shortest path between the } \\
\text { segments in a } 10 \AA \text {-radius } \\
\text { patch }\end{array}$ & \\
\hline & \multirow[t]{6}{*}{$\begin{array}{l}\text { Prime methods } \\
\text { with ALA linker }\end{array}$} & NNala & NN with ALA linker & $\begin{array}{l}\text { segments in the natural } \\
\text { orientation }\end{array}$ & $\begin{array}{l}\text { ALA linkers inserted between } \\
\text { segments of NN method }\end{array}$ & \\
\hline & & uNNala & $\begin{array}{l}\text { upset NN with ALA } \\
\text { linker }\end{array}$ & $\begin{array}{l}\text { segments in the natural } \\
\text { orientation }\end{array}$ & $\begin{array}{l}\text { ALA linkers inserted } \\
\text { between segments of UNN } \\
\text { method }\end{array}$ & \\
\hline & & ONNala & $\begin{array}{l}\text { Optimized NN with } \\
\text { ALA linker }\end{array}$ & $\begin{array}{l}\text { segments in the natural } \\
\text { orientation }\end{array}$ & $\begin{array}{l}\text { ALA linkers inserted between } \\
\text { segments of ONN method }\end{array}$ & \\
\hline & & FNala & $\begin{array}{l}\text { Flanking NN with } \\
\text { ALA linker }\end{array}$ & $\begin{array}{l}\text { segments in the natural } \\
\text { orientation }\end{array}$ & $\begin{array}{l}\text { ALA linkers inserted between } \\
\text { segments of FNN method }\end{array}$ & \\
\hline & & OFNala & $\begin{array}{l}\text { Optimized Flanking } \\
\text { NN with ALA linker }\end{array}$ & $\begin{array}{l}\text { segments in the natural } \\
\text { orientation }\end{array}$ & $\begin{array}{l}\text { ALA linkers inserted between } \\
\text { segments of OFN method }\end{array}$ & \\
\hline & & OPPala & $\begin{array}{l}\text { Optimized Patched } \\
\text { segments path with } \\
\text { ALA linker }\end{array}$ & $\begin{array}{l}\text { segments in the natural } \\
\text { orientation }\end{array}$ & $\begin{array}{l}\text { ALA linkers inserted between } \\
\text { segments of OPP method }\end{array}$ & \\
\hline & \multirow[t]{5}{*}{$\begin{array}{l}\text { Prime methods } \\
\text { with structural- } \\
\text { based linker }\end{array}$} & NNsa & NN with SA linker & $\begin{array}{l}\text { segments in the natural } \\
\text { orientation }\end{array}$ & $\begin{array}{l}\text { Linkers computed from SA } \\
\text { inserted between segments } \\
\text { of NN method }\end{array}$ & \\
\hline & & ONNsa & $\begin{array}{l}\text { Optimized NN with } \\
\text { SA linker }\end{array}$ & $\begin{array}{l}\text { segments in the natural } \\
\text { orientation }\end{array}$ & $\begin{array}{l}\text { Linkers computed from SA } \\
\text { inserted between segments } \\
\text { of ONN method }\end{array}$ & \\
\hline & & FNsa & $\begin{array}{l}\text { Flanking NN with SA } \\
\text { linker }\end{array}$ & $\begin{array}{l}\text { segments in the natural } \\
\text { orientation }\end{array}$ & $\begin{array}{l}\text { Linkers computed from SA } \\
\text { inserted between segments } \\
\text { of FNN method }\end{array}$ & \\
\hline & & OFNsa & $\begin{array}{l}\text { Optimized Flanking } \\
\text { NN with SA linker }\end{array}$ & $\begin{array}{l}\text { segments in the natural } \\
\text { orientation }\end{array}$ & $\begin{array}{l}\text { Linkers computed from SA } \\
\text { inserted between segments } \\
\text { of OFN method }\end{array}$ & \\
\hline & & OPPsa & $\begin{array}{l}\text { Optimized Patched } \\
\text { segments Path with } \\
\text { SA linker }\end{array}$ & $\begin{array}{l}\text { segments in the natural } \\
\text { orientation }\end{array}$ & $\begin{array}{l}\text { Linkers computed from SA } \\
\text { inserted between segments } \\
\text { of OPP method }\end{array}$ & \\
\hline & \multirow{3}{*}{$\begin{array}{l}\text { Prime methods } \\
\text { with superposed } \\
\text { structural-based } \\
\text { linker }\end{array}$} & NNsas & NN with SAS linker & $\begin{array}{l}\text { segments in the natural } \\
\text { orientation }\end{array}$ & $\begin{array}{l}\text { Linkers computed from SAS } \\
\text { inserted between segments } \\
\text { of NN method }\end{array}$ & \\
\hline & & ONNsas & $\begin{array}{l}\text { Optimized NN with } \\
\text { SAS linker }\end{array}$ & $\begin{array}{l}\text { segments in the natural } \\
\text { orientation }\end{array}$ & $\begin{array}{l}\text { Linkers computed from SAS } \\
\text { inserted between segments } \\
\text { of ONN method }\end{array}$ & \\
\hline & & FNsas & $\begin{array}{l}\text { Flanking NN with } \\
\text { SAS linker }\end{array}$ & $\begin{array}{l}\text { segments in the natural } \\
\text { orientation }\end{array}$ & $\begin{array}{l}\text { Linkers computed from SAS } \\
\text { inserted between segments } \\
\text { of FNN method }\end{array}$ & \\
\hline
\end{tabular}


Table 1 PEPOP 2.0 methods and their main characteristics (Continued)

\begin{tabular}{|c|c|c|c|c|c|c|}
\hline Category & Sub category & Name & Full name & Composing elements & Characteristic & $\begin{array}{l}\text { Epitope type } \\
\text { mimetic }\end{array}$ \\
\hline & & OFNsas & $\begin{array}{l}\text { Optimized Flanking } \\
\text { NN with SAS linker }\end{array}$ & $\begin{array}{l}\text { segments in the natural } \\
\text { orientation }\end{array}$ & $\begin{array}{l}\text { Linkers computed from SAS } \\
\text { inserted between segments } \\
\text { of OFN method }\end{array}$ & \\
\hline & & OPPsas & $\begin{array}{l}\text { Optimized Patched } \\
\text { segments path with } \\
\text { SAS linker }\end{array}$ & $\begin{array}{l}\text { segments in the natural } \\
\text { orientation }\end{array}$ & $\begin{array}{l}\text { Linkers computed from SAS } \\
\text { inserted between segments } \\
\text { of OPP method }\end{array}$ & \\
\hline \multirow[t]{12}{*}{$\begin{array}{l}\text { Graph } \\
\text { Theory }\end{array}$} & SHP methods & SHPnat & SHP natural & $\begin{array}{l}\text { segments in the natural } \\
\text { orientation }\end{array}$ & $\begin{array}{l}\text { Shortest path between } \\
\text { segments using Dijkstra's } \\
\text { algorithm }\end{array}$ & \\
\hline & & SHPrev & SHP reverse & $\begin{array}{l}\text { segments in the natural or } \\
\text { reverse orientation }\end{array}$ & $\begin{array}{l}\text { Shortest path between } \\
\text { segments using Dijkstra's } \\
\text { algorithm }\end{array}$ & \\
\hline & & SHPaa & SHP amino acids & amino acids & $\begin{array}{l}\text { Shortest path between } \\
\text { segments using Dijkstra's } \\
\text { algorithm }\end{array}$ & \\
\hline & TSP methods & TSPnat1 & TSP natural 1 & $\begin{array}{l}\text { segments in the natural } \\
\text { orientation }\end{array}$ & $\begin{array}{l}\text { Shortest path between } \\
\text { segments using Dantzig \& } \\
\text { Fulkerson's algorithm and } \\
\text { most favorable interacting } \\
\text { parameters }\end{array}$ & \\
\hline & & TSPnat2 & TSP natural 2 & $\begin{array}{l}\text { segments in the natural } \\
\text { orientation }\end{array}$ & $\begin{array}{l}\text { Shortest path between } \\
\text { segments using Dantzig \& } \\
\text { Fulkerson's algorithm }\end{array}$ & \\
\hline & & TSPnat3 & TSP natural 3 & $\begin{array}{l}\text { segments in the natural } \\
\text { orientation }\end{array}$ & $\begin{array}{l}\text { Shortest path using Dantzig } \\
\text { \& Fulkerson's algorithm } \\
\text { according to the number } \\
\text { of segments }\end{array}$ & \\
\hline & & TSPnat4 & TSP natural 4 & $\begin{array}{l}\text { segments in the natural } \\
\text { orientation }\end{array}$ & $\begin{array}{l}\text { Shortest path using Dantzig } \\
\text { \& Fulkerson's algorithm } \\
\text { including the } 2 \text { closest } \\
\text { segments }\end{array}$ & \\
\hline & & TSPrev1 & TSP reverse 1 & $\begin{array}{l}\text { segments in the natural or } \\
\text { reverse orientation }\end{array}$ & $\begin{array}{l}\text { Shortest path using Dantzig } \\
\text { \& Fulkerson's algorithm and } \\
\text { most favorable interacting } \\
\text { parameters }\end{array}$ & \\
\hline & & TSPrev2 & TSP reverse 2 & $\begin{array}{l}\text { segments in the natural or } \\
\text { reverse orientation }\end{array}$ & $\begin{array}{l}\text { Shortest path using Dantzig } \\
\& \text { Fulkerson's algorithm }\end{array}$ & \\
\hline & & TSPrev3 & TSP reverse 3 & $\begin{array}{l}\text { segments in the natural or } \\
\text { reverse orientation }\end{array}$ & $\begin{array}{l}\text { Shortest path using Dantzig } \\
\text { \& Fulkerson's algorithm } \\
\text { according to the number } \\
\text { of segments }\end{array}$ & \\
\hline & & TSPrev4 & TSP reverse 4 & $\begin{array}{l}\text { segments in the natural or } \\
\text { reverse orientation }\end{array}$ & $\begin{array}{l}\text { Shortest path using Dantzig } \\
\text { \& Fulkerson's algorithm } \\
\text { including the } 2 \text { closest } \\
\text { segments }\end{array}$ & \\
\hline & & TSPaa & TSP amino acids & amino acids & $\begin{array}{l}\text { Shortest path using Dantzig } \\
\text { \& Fulkerson's algorithm }\end{array}$ & \\
\hline
\end{tabular}

ALA alanine, NN nearest neighbor, SA structural alphabet, SAS superposed structural alphabet, SHP SHortest Path algorithm, TSP Traveling Salesman Problem algorithm

peptides that will be used to generate anti-protein Abs. The 'Peptide Bank Design' section of the PEPOP 2.0 web site is dedicated to the design of peptides that will be used for their antigenic properties. For this section, two types of experiments have been illustrated: the mapping of discontinuous epitopes and the identification of inhibitor peptides.

\section{Designing peptides to generate anti-protein abs}

The 'One Specific Peptide Design' section of the PEPOP 2.0 web site is dedicated to the prediction of one peptide at a time. This section already existed in the previous version of PEPOP 2.0 but was updated and enriched with new methods. This section allows defining only a small number of peptides. The peptide is progressively 


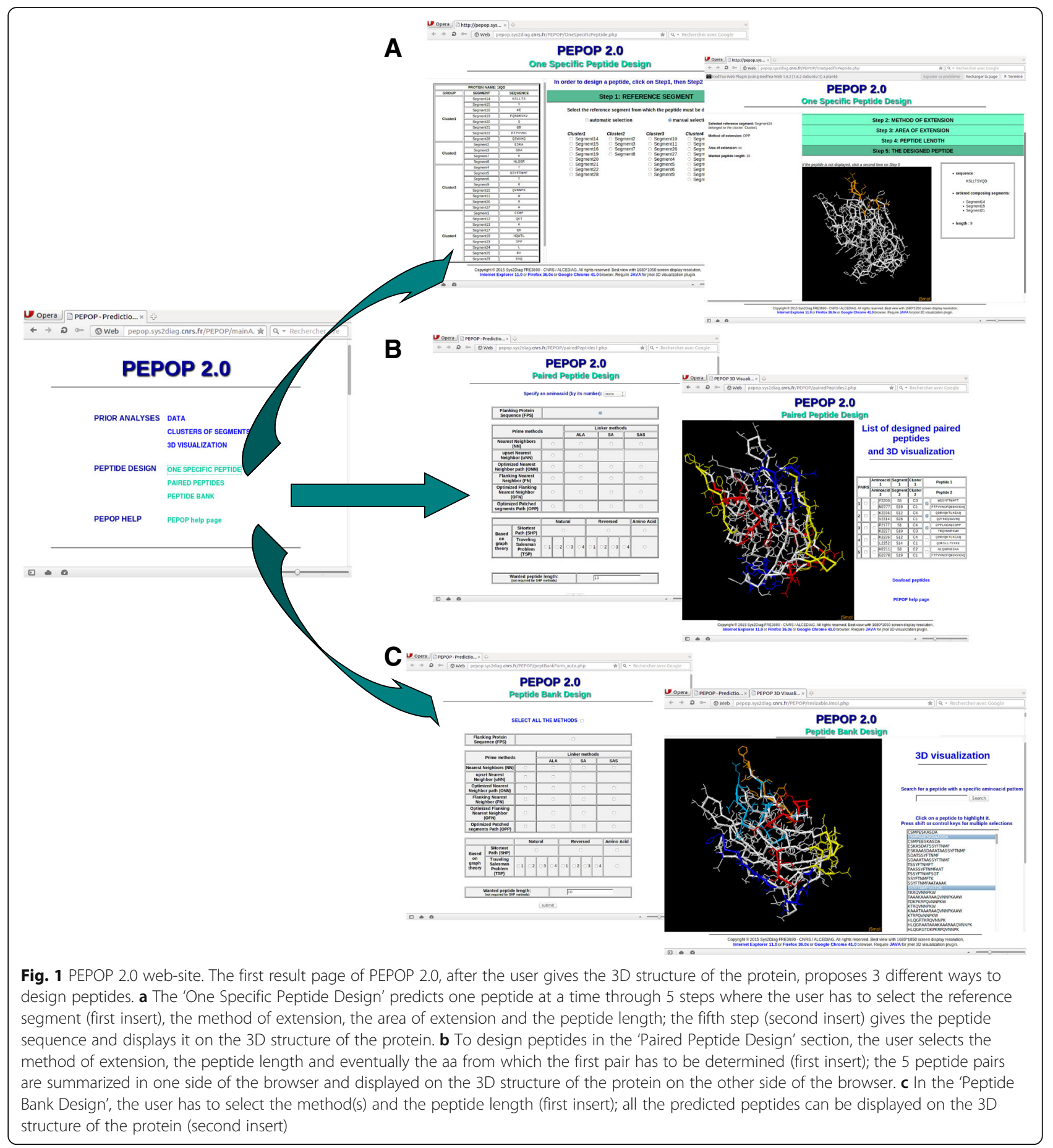

built through 4 steps: the reference segment, the method of extension, the area of extension and the peptide length. At each step, a choice is selected by default so that at the end the peptide can be built automatically. Instead, the user may control the choices and the parameters (the 5 physicochemical and structural criteria: hydrophobicity, accessibility, segment length, $\beta$-turn content, WRYP content) at any step.
Using this section of PEPOP, we designed a peptide from the 3D structure of the LMW (low molecular weight) form of adiponectin (PDB code: $1 \mathrm{C} 3 \mathrm{H}$ ). The peptide KYGDGDHNGLYADVETR has been predicted by the OFN method and gathered 4 segments: sequentially, segment $70(\mathrm{~K})$, segment 80 (YGDGDHNGLYAD), segment $81(\mathrm{~V})$, and segment 58 (ETR). The OFN method adds the sequence of the nearest neighbor segment 


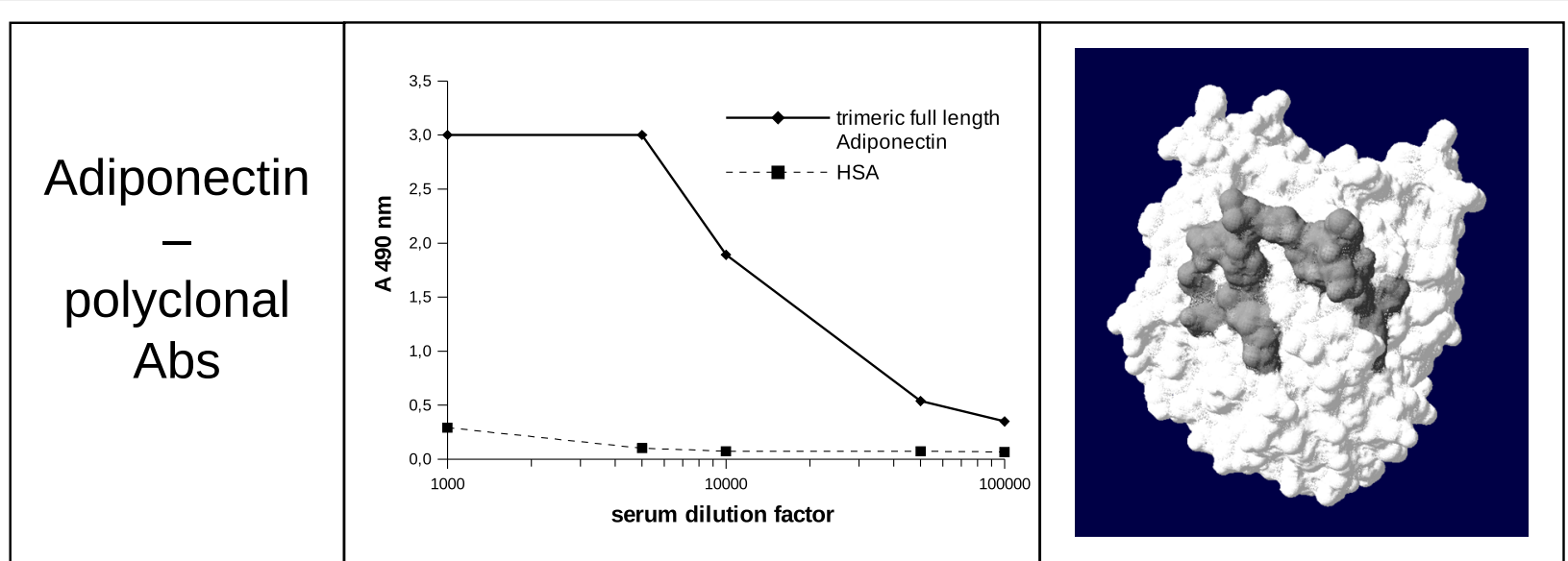

Fig. 2 Reactivity of mouse immune serum raised using a "discontinuous" peptide against trimeric full length adiponectin (LMW adiponectin) and a control protein (HSA). The segments composing the peptide are displayed on the surface of the protein

C-terminally and then $\mathrm{N}$-terminally until the requested length of the peptide is reached. We chose this method, new in this version of PEPOP 2.0, because we think it could be important to keep the reference segment in a central position in the peptide to be more easily recognized by the Ab. After peptide mouse immunization, we observed that Abs against the predicted "discontinuous" adiponectin peptide were able to recognize the trimeric full-length adiponectin but did not recognize the human serum albumin (Fig. 2). The representation of the segments on the 3D structure of the protein clearly shows that despite the fact that they are not contiguous on the sequence, they are gathered in one region of the protein (Fig. 2). This result showed that PEPOP 2.0 successfully designs a peptide able to generate Abs targeting a discontinuous epitope on the cognate Ag.

\section{Designing peptides to generate abs capturing the cognate protein}

The 'Paired Peptides Design' section is new in this improved version of PEPOP 2.0. It is dedicated to the prediction of pairs of peptides. The goal is to target specific and distinct regions on the protein: the predicted peptides can then be used to prepare Abs that should be able to capture the cognate protein. The principle is to select two candidate peptides that are appropriately structurally separated in the 3D model. PEPOP 2.0 proposes up to 5 pairs of distinct peptides. The peptides are designed by computing the most distant pairs of surface accessible aa and the two orthogonal most distant pairs in order to give the best chance for the generated Abs to capture the Ag without steric hindrance. Two more pairs are proposed as an alternative in the event that a targeted region is too close to the first one. This would lead to steric hindrance for the Abs generated. The user can orientate the design by indicating the position of one of the two aa of the first pair. The other pairs will be designed consequently. Figure 3 shows an example of the three first paired peptides on the A2 domain of FVIII. The six peptides are in distinct and opposite (two by two) regions of the protein. The recognition of the protein by the Abs generated by such peptides should not be disturbed by steric hindrance. The Abs should capture the protein two by two. This section of PEPOP 2.0 can be a useful tool for the characterization of the proteins after a process of high throughput selection or for the development of a kit for diagnosis.

We showed how PEPOP 2.0 can propose peptides to use in immunogenic experiments. The designed peptides can also be used for their antigenic properties.

\section{Designing peptides to map discontinuous epitopes}

The new section 'Peptide Bank Design' has been designed to propose an alternative to the existing timeand ressource-consuming methods used to map discontinuous epitopes. The idea is to use a mixture of experiments to map continuous (high-throughput peptide synthesis, e.g. SPOT technology [37, 38]) and discontinuous epitopes (e.g. phage-display). As all the epitope information is already contained on the protein, experimental design is best suited by only testing the most numerous possible peptides, as in phage-display experiment. We drastically reduced the peptide search space by using protein information and methods carefully considered to address antigenic properties. The virtual peptide sequence bank is constructed thanks to a flexible web interface where the user has to choose the methods of extension and the peptide length (set to 10 aa length by default). Each method predicts all the possible peptides. For example, in the case of the prime, ALA, SA, and SAS methods, all the segments determined by 


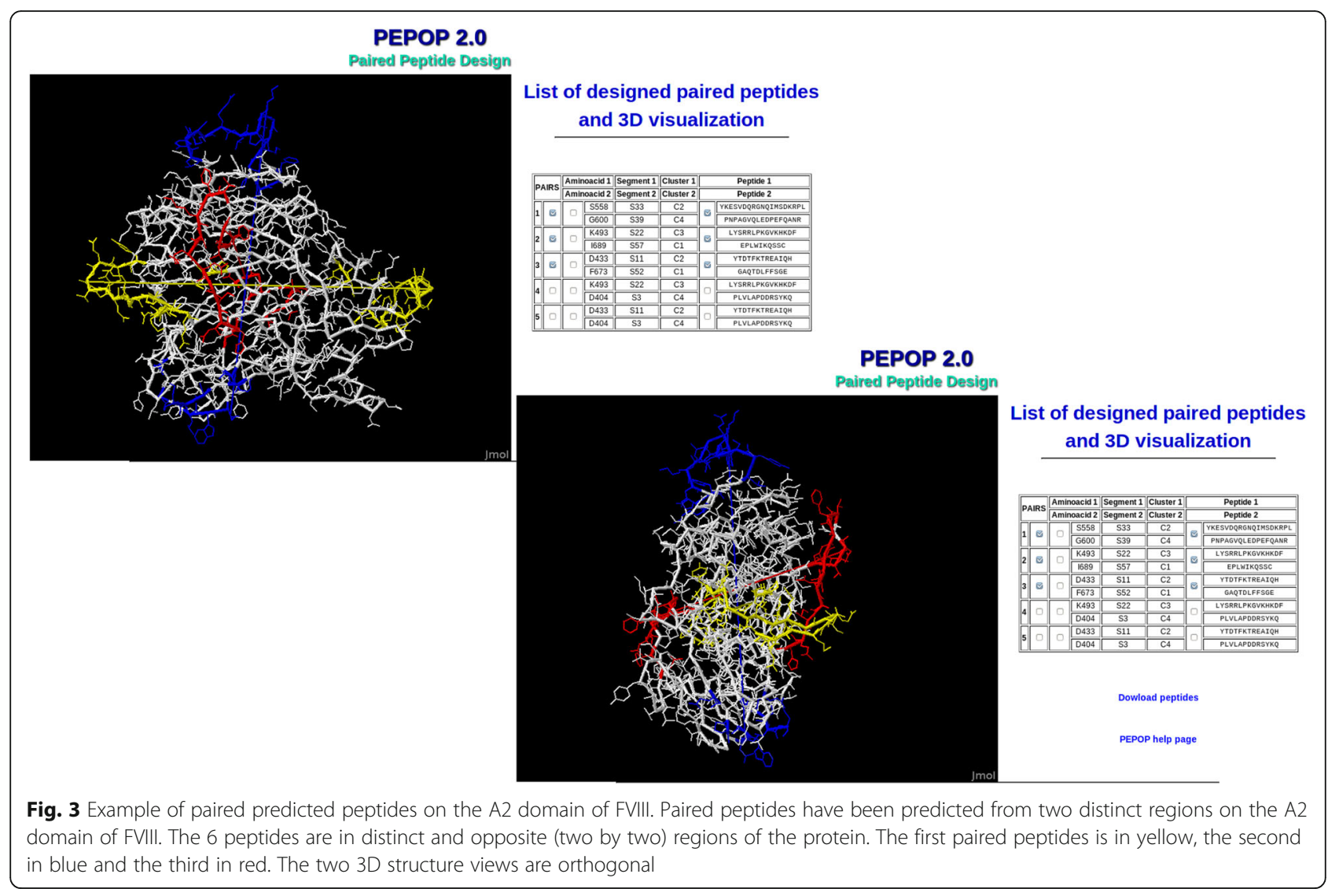

PEPOP 2.0 are individually selected as the reference segment. Thus, the method predicts as many peptides as segments. In this way, the entire surface of the protein is explored. Moreover, using several methods allows the testing of different arrangements of the same segments in peptides. Indeed, as we do not really know what governs the antigenic rules, we do not really know how some peptide characteristics, such as the peptide conformation, the aa position, the aa spacing, or the aa order influence the interaction with the Ab. The predicted peptides can be visualized on the 3D structure of the protein one or several at a time.

Using this methodology we map discontinuous epitopes either recognized by a pAbs on Amm8 [35] or recognized by mAbs on AaH II (Duarte $\mathrm{C}$ et al., A mimic of a discontinuous epitope from $\mathrm{AaH}$ II identified by combining wet and dry experiments: a new experimental methodology to localize discontinuous epitopes, in preparation) and GM-CSF (Abraham J-D et al., Combination of bioinformatics and experimental approaches to map the conformational epitope on GM-CSF, in preparation). Figure 4 shows three more studies mapping discontinuous epitopes on LiD1 recognized by LimAb7 mAb $[39,40]$ and GAD65 recognized by DPC $\mathrm{mAb}$ and Ab54 mAb. Using prime, ALA, and SA methods with a requested peptide length of 10 aa, 456, and 648 peptides were predicted from the 3D model of LiD1 [41] and the 3D structure of GAD65 (PDB code: 2OKK) respectively. Peptides shorter than 7 aa have been eliminated because it is considered that the peptide is too short to well mimic the discontinuous epitope. Peptides longer than 24 aa have been eliminated due to synthesis performance limitations. Peptides have been synthesized using the SPOT method and their immune reactivities were tested with their respective mAb. In the case of LiD1, only one peptide has been recognized: it is displayed on the 3D structure of the protein. For GAD epitopes, several peptides have been identified. However, the control experiment with only anti-Fc pAbs reveals the reactivity of several peptides. By subtracting them, two specific spots appear that are only recognized by the mAb. According to the mAb, either DPC or Ab54, the two spots are different. The peptides representative of discontinuous epitopes are displayed on the 3D structure of GAD65. These results, with previous studies [35] (Duarte C et al., A mimic of a discontinuous epitope from $\mathrm{AaH}$ II identified by combining wet and dry experiments: a new experimental methodology to localize discontinuous epitopes, in preparation; Abraham J-D et al., Combination of bioinformatics and experimental approaches to map the conformational epitope on GM-CSF, in preparation), showed that PEPOP 2.0 


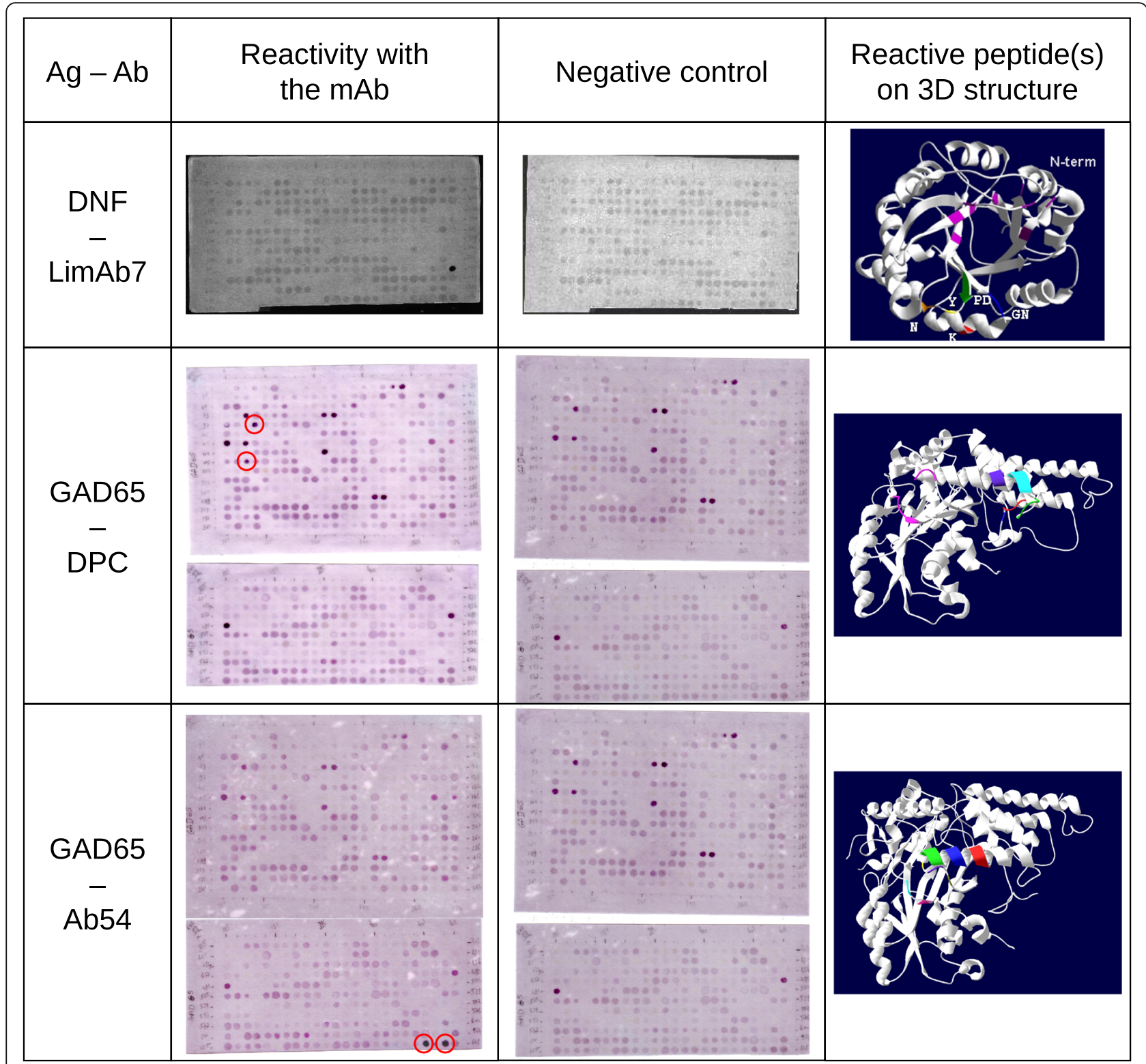

Fig. 4 Reactivity of monoclonal antibodies, LimAb7, DPC and GAD65 with "discontinuous" peptides predicted from the 3D structure of respectively LiD1 and GAD65. The peptides have been prepared by the Spot technology. The reactivity was controlled with anti-Fc pAbs alone. The reactive peptides with the mAb are displayed on the 3D structure of the corresponding protein

successfully designs "discontinuous" peptides able to be recognized by the Abs allowing the localization of the targeting discontinuous epitopes on the cognate Ag.

\section{Designing peptides to identify inhibitor peptides}

Another way to use the 'Peptide Bank Design' section of the PEPOP 2.0 web site is to test the antigenicity of the predicted peptides synthesized in soluble form with Abs in order to select peptides that could replace the cognate protein. Prediction of epitopes could have potential clinical implications in hemophilia A (HA), an inherited bleeding disorder. Indeed, severe $\mathrm{HA}$ is defined by an undetectable level of coagulation factor VIII (FVIII). The treatment of HA is based on regular intravenous infusions of FVIII and, to date, the main complication (up to $30 \%$ of severe HA patients) of this treatment is the development of inhibitory anti-FVIII Abs. The development of this immune response dramatically impacts the care of HA patients, and a fine epitope mapping could be helpful for a better understanding of the physiopathology and the treatment of such complications. As anti-FVIII Abs are mainly directed against $\mathrm{C} 2$ and A2 domain of FVIII, we predicted peptides mimicking discontinuous epitopes of these domains [42, 43]. 


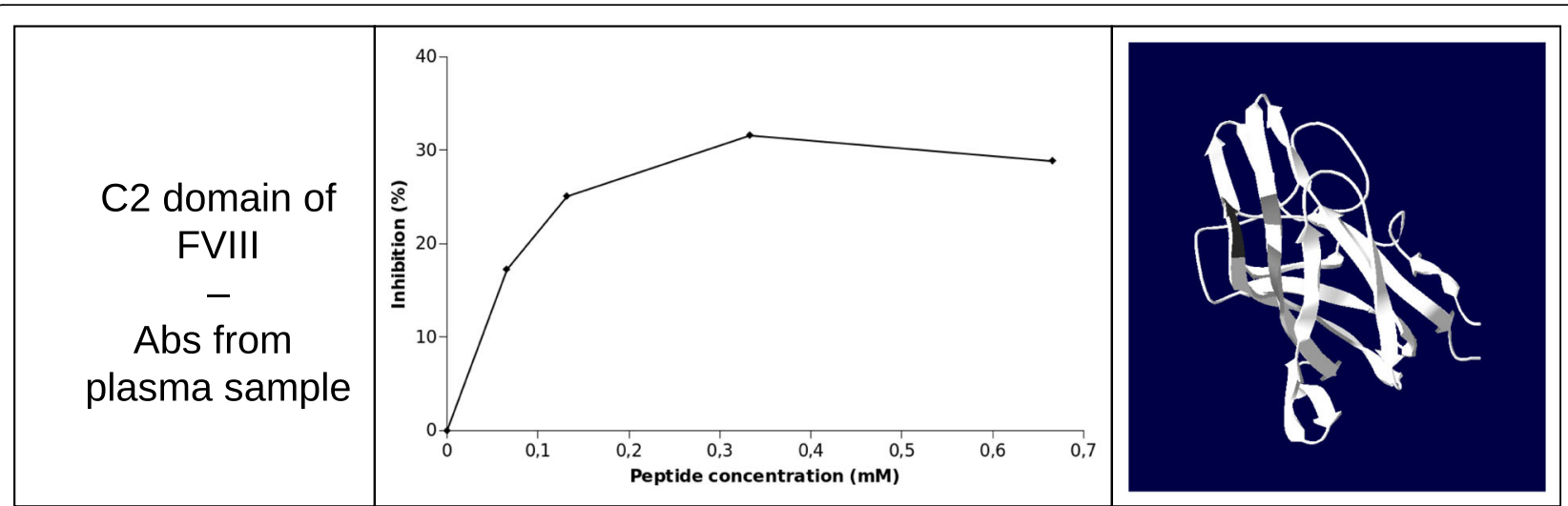

Fig. 5 Inhibition obtained with different amounts of a peptide representative of the C2 domain of FVIII in x-MAP inhibition assays using plasma sample

For example, we synthesized 33 synthetic peptides potentially representative of discontinuous epitopes on the $\mathrm{C} 2$ domain of coagulation FVIII, using the OPP method of PEPOP 2.0 [42]. Only one method has been selected in the 'Peptide Bank Design' section. As the experiments are relatively costly (in time and money) and need a large amount of plasma, all the peptides from the methods cannot be tested and a limited number of peptides needed to be selected. One solution is to select only one method. We chose this method because the reference segment is central in the patch, it contains no aa linker which could interfere with the Ab binding, and the search of the path between the segments is optimized. In this way, the peptides together still allow exploring the entire surface of the protein. Using an inhibition assay based on the $\mathrm{x}$-MAP technology, we evaluated their ability to block the binding to the $\mathrm{C} 2$ domain of anti-C2 domain Abs from plasma samples. Figure 5 shows one of the reactive peptides blocking the $\mathrm{Ab}$ binding in a dose-dependent manner. The peptides inhibit the interaction between the $\mathrm{C} 2$ domain of FVIII and the Abs by around 30\%. The same protocol with another PEPOP method, TSPaa, was used to predict peptides mimicking discontinuous epitopes of the A2 domain of FVIII [43]. So, we show that it is possible to find at least one peptide in a series predicted by PEPOP 2.0 that inhibits an Ab-Ag interaction. These results showed that PEPOP 2.0 successfully designs "discontinuous" peptides able to be recognized by the Abs targeting the cognate Ag.

For all sections of the PEPOP 2.0 web site, the location of the predicted peptides can be displayed on the 3D structure of the protein.

\section{Discussion}

By presenting the improved version of the PEPOP 2.0 web-site, we showed the ways to use predicted peptides expected to mimic discontinuous epitopes. The most often use of the peptides is the generation of anti- protein Abs. One of the two great novelties of PEPOP 2.0 is the use of peptides by pair so as to target distinct regions on the surface of the protein and generate Abs that should be able to capture the protein. This can be a useful tool, for example, in the characterization of biomarkers after the process of discovery in highthroughput selection. Notably, it could lead to the development of diagnosis kits. The other novel feature of PEPOP 2.0 is the 'Peptide Bank Design' section of the web-site. Because we predict from the native Ag, we showed that only a limited number of peptides (compared to the diversity generated in phage-display method) is necessary to map discontinuous epitopes. After synthesis, the functionality of the peptides exploring all the surface of the protein could be assessed in a convenient high-throughput recognition assay, such as the SPOT method $[35,44,45]$ or other technologies [46]. If the correct sequence is present in the bank, the Ab should recognize it and this identifies the epitope region on the protein. Then, a set of peptides around the space of the epitope region identified can be tested in further experiments to more precisely hone the epitope or to select a functional peptide. The final feature we tested is the search for an inhibitor. We synthesized, in soluble form, a restricted list of peptides and tested their capacity to inhibit the interaction between the protein and Abs. We showed that it is possible to select peptides able to replace discontinuous epitopes in an Ag-Ab interaction.

Two opposing views exist about epitopes. The first view considers that a protein is constituted by a mosaic of overlapping epitopes $[47,48]$. It is therefore theoretically possible to generate Abs against any region of the protein surface. Specific phenomena such as, for example, central and peripheral immunotolerance [49], repetitive fragments [50] or aggregates [51] can induce variations in the immune response. However, using different hosts or different techniques [52-56] would allow 
the systematic acquisition of Abs. Any region on a protein is a potential epitope. The other point-of-view considers that proteins have only a few epitopes preferentially recognized by the immune system $[57,58]$. In view of these two hypotheses, it is not surprising that Blythe and Flower found that the continuous epitope prediction tools are not better than chance [20] and that the discontinuous epitope prediction tools showed weak performances [36]. In the first hypothesis, a tool cannot find any region emerging from the others since it is possible to produce Abs targeting any surface of the protein. In the other hypothesis, it would likely be logistically impossible for a tool to well predict when the learning data are a mix of a variety of different epitopes (immunogen, epitopes generated from peptides, truncated protein, cross-reacting molecules) [59]. Theoretically, a tool cannot predict an epitope because an epitope only exists thanks to the existence of the Ab recognizing it. To know whether it is really possible to predict epitopes ab initio, the existence of immunodominant regions should be proved or refuted, for example with systematic studies by categorizing Ag-Ab complexes, distinguishing epitope types and origins. Perhaps, we will discover that it is an intermediary or both of the two hypotheses: the immune system could preferentially target few specific regions on the protein (would it be just a question of surface accessibility?) but it is still possible to produce Abs targeting any regions $[60,61]$. Whatever the reality, in the present state of knowledge, the only way to predict an epitope is to take into account the Ab [62].

Predicting an epitope begins by proposing a region on the protein, i.e. a set of aa. Peptide prediction tools have to determine the sequence from this set by determining an arrangement, a disposition, a path between the aa. This can be very difficult. More elements have to be combined, and as the problem becomes more complex, it becomes rapidly unsolvable. This is an NP-complex problem relying on combinatorial mathematics. Solutions have to be found because it is impossible to enumerate all the possibilities.

Moreover, although the $\mathrm{Ag}-\mathrm{Ab}$ interactions have been deeply studied [63-66], the mimicking of a discontinuous epitope by a linear peptide is still a challenging task [67]. Other parameters than those found in protein-protein interface studies [68-70] have to be taken into account. Should the peptide adopt the same conformation as in the protein so the Ab can recognize it? Would the peptide be in the same conformation in the protein context? Chen et al. [65] showed that the conformations of the peptides compared to those of the corresponding regions on the proteins when complexed with the Ab have considerable differences. It should be even more difficult because the structure of an epitope when it is complexed with the $\mathrm{mAb}$ tends to differ from the structure before the mutual adaptation process [71]. Should the aa be spaced out as in the protein so that they are correctly laid out to allow the CDR loops of the Ab to properly face and interact with them? Or, is it sufficient for the key aa to be present in the peptide whatever their disposition? In reality, molecular mimetism is poorly understood. It would be very informative to carry out systematic studies in order to fully elucidate this phenomenon. In this way, PEPOP 2.0 can be seen as a "test tube" to help to better understand molecular mimicry.

As molecular mimicry is still poorly understood, it is difficult to predict which peptide compared to another will be recognized by a specific $\mathrm{Ab}$ even if they are both composed of the same key aa. Consequently, it might be considered whether a scoring function is conceivable. We have deliberately chosen not to rank peptides: we would not know which rules are really important. Moreover, we think bioinformatics predictions cannot be used as such and have to be always associated to experiments. Combining bioinformatics predictions and simple experimental methods can be an interesting alternative to expensive and time-consuming approaches. The section "Peptide Bank Design" has been developed in the idea that it can be used in epitope mapping by associating it with SPOT methods. Somehow, the experiment replaces the scoring function: for a reduced time and cost, a more confident result is gained.

Moreover, there is a real advantage in using mimicking peptides. Beyond avoiding the difficulties of obtaining a pure preparation of the protein, reduction in cost, and increased ease in manipulation, even with polyclonal Abs the regions targeted on proteins are well known. The main advantage of using "discontinuous" peptides is that the final Abs should recognize the native well-structured protein Ag. Moreover, the same series of peptides can be probed by different Abs raised against the same target $\mathrm{Ag}$, so as to disclose the cognate epitope of each.

However, the experimentalists have to carefully think through their experiments before designing peptides because, as van Regenmortel underlined at a workshop about the current state and future directions for the epitope prediction field [72], the results can be different according to the experiment. For example, a peptide seen reactive in SPOT could be found not interacting in the soluble form in ELISA. It may be due to the different conformation the peptide adopts according to whether it is linked to a support or totally free in solution. It also may be due to the phenomenon of avidity in SPOT. Thus, if the experimentalist wants to map the epitope, (s)he can carry out SPOT experiments or other highthroughput technologies. But, if (s)he wants to use the reactive peptide in further experiments, (s)he has to keep in mind that they may not react the same way. This is why it is recommended for the experimentalist 
searching for an inhibitory peptide to select it by using technology that will present the peptides in its final format. Furthermore, the experimentalist also has to carefully choose the peptide design methods according to the objectives of the experiment. If the aim is to generate Abs, it would be better not to use linker methods in order to avoid Abs that are directed against the linker aa, which could lead to Abs not cross-reacting with the protein. If the aim is to find an inhibitory peptide (experiments in soluble form), it is recommended to use peptide design methods that search for an optimized path (ONN, OFN, OPP, graph-based methods).

\section{Conclusion}

Assigning a function to each new protein structure resulting from high-throughput genomics experiments is a huge task. For example, the current techniques for epitope mapping are unfeasible on a genomic scale due to the high cost and effort needed. Reliable computational methods can assist by offering fast, scalable, and cost-effective approaches for identifying B-cell epitopes, focusing on experimental studies and improving our understanding of Ag- $\mathrm{Ab}$ interactions. In silico tools such as PEPOP 2.0, designing immunogenic or antigenic peptides representative of a given protein should help experimentalists to handle proteins by turning them into peptides, which are smaller and easier to manipulate. They can aid with future goals in the area of the discovery of biomarkers by providing solutions to characterize these molecules or develop probes to capture them, leading to diagnosis and therapy applications. PEPOP 2.0, and its potential counterparts, will also be useful tools to discover and study the rules governing molecular mimicry by testing the different approaches developed in the peptide design methods through systematic studies on antigenicity or immunogenicity. The flexibility of PEPOP 2.0 allows other problems to be addressed. For example, one can compare the peptides representing the surface of two proteins known to interact with the same mAb. Or, as PEPOP 2.0 explores the surface of any protein, it can potentially be used to investigate any protein-protein interaction: the Ab would be replaced by another protein interacting with a targeted protein. Therefore, the protein-protein interaction site or an inhibitory peptide could be searched for in the same way. This opens the door to an even greater world of possibilities in diagnosis or therapy applications.

\section{Methods \\ PEPOP 2.0 \\ Principle}

To predict a peptide, the first step is the computing of the surface accessible amino acids (aa) using default parameters of DSSP [38]. Continuous segments are then deduced. The second step is the determination of the segment or aa combination which will form the final peptide. To assemble the segments or the aa in an arrangement the $\mathrm{Ab}$ will be able to recognize, thirty-four methods can be used. They are based on different algorithms (for more details see Table 1 and (Demolombe V et al., Benchmarking the PEPOP methods for mimicking discontinuous epitopes, submitted)). The segments or aa used to build the final peptide come from a defined area of about an epitope size on the protein. The possible areas in PEPOP 2.0 can be either clusters of clustered segments according to their spatial distances or patches of $10 \AA, 15 \AA$, and varying radii.

\section{Patch definitions}

A patch gathers the segments or aa present inside a radius from the $\mathrm{G}$ point of a reference (segment or aa, selected by the user or by default) to a defined distance. PEPOP 2.0 uses three types of patches. The $10 \AA$ - and $15 \AA$-radius patches gather the segments in the fixed distance of $10 \AA$ and $15 \AA$ respectively. In the varying patch, the patch gathers the aa in the distances varying from 15 to $20 \AA$ : the final radius corresponds to the one for which the number of aa collected is the average number of aa between radius $15,16,17,18,19$ and $20 \AA$.

\section{Prediction of paired peptides}

The first step is to determine the distant aa. Then, the peptides are designed according to the method either by considering the aa or the segment including it as the reference (starting point).

The first pair of distant aa is the two most distant surface accessible aa of the protein. To find the second pair of aa, an orthogonal plane to the first pair of aa is drawn. The two most distant aa around $5 \AA$ from this plane are sought. A distance from the plane has to be tolerated, otherwise the plane could cross a zero aa threshold. The third pair is the two most distant aa included in the 10 $\AA$-thickness perpendicular bisector to the first and the second pairs of aa. The fourth and fifth pairs are proposed as an alternative to the second and third pair, respectively. The fourth pair of aa consists of one of the two aa of the second pair and the most distance of all the surface-accessible aa of the protein. The fifth pair of aa is the most distant pair where one is one of the two aa of the third pair and the other is found among all the surface-accessible aa of the protein.

\section{Web interface}

PEPOP 2.0 has been implemented on a virtualized Linux server kernel 2.6 running the Apache web server version 2.2.15. The tool has been implemented in object-oriented PHP and JavaScript, and uses scripts and software developed in PERL, C, and C++. Segments, clusters, and 
peptides identified by PEPOP 2.0 can be directly visualized on the 3D structure of the Ag thanks to jsmol. PEPOP 2.0 is available at https://www.sys2diag.cnrs.fr/index. php?page=pepop.

\section{Experiments}

\section{Synthesis of spot peptides}

The peptide analogs were prepared by Spot synthesis [73] on a cellulose membrane, as previously described by Laune et al. [74]. Membranes were obtained from Proteigene. A Multipep robot (Intavis) was used for the coupling steps. Peptides were acetylated at the $\mathrm{N}$-terminus. After the peptide sequences were assembled, the side-chain protecting groups were removed by trifluoroacetic acid treatment, but peptides remained attached on the membrane for ELISA-Spot experiments. Briefly, after an overnight saturation step with 3\% BSA, the set of membrane bound peptides were probed by incubation with the mAb of interest. After 90 min incubation at room temperature, the membrane was washed and incubated for $1 \mathrm{~h}$ at room temperature with a peroxidase-conjugated anti-mouse or anti-human $\mathrm{Ab}$ (Sigma, diluted 1:3000). The spots were stained with enhanced chemiluminescent ECL detection kit (Amersham). The reactivity of each membrane was assessed in at least three independent experiments.

\section{Synthesis of the "discontinuous" adiponectin soluble peptide and the coagulation FVIII soluble peptides}

The soluble peptides were synthesized on a Multipep Synthesizer using fluorenylmethyloxycarbonyl (Fmoc) acting as a protective group $[75,76]$ with a HOBt-DIPC protocol. The C-terminal residues were first fixed to the solid phase support and $\mathrm{NH} 2$ extremity, and R groups are initially protected by Fmoc. After a basic deprotection of the NH2 extremity of the first fixed aa, the second protected aa was added and its carboxyl function activated to allow for the peptide linkage and extension of the peptides. The peptides were elongated after a succession of protection/deprotection steps until the addition of the last residue. Lateral chains were subsequently deprotected and the peptides released from the resin by trifluoroacetic acid treatment in the presence of the appropriate scavengers in order to generate amidated peptides. After synthesis, the peptides were lyophilized and the quality of the peptides was verified by high performance liquid chromatography and mass spectrometry.

\section{Immune response to the "discontinuous" adiponectin peptide}

Mouse immunization Eight-week-old Balb/C male mice from Harlan (Gannat, France) were immunized with KLH-conjugated discontinuous adiponectin peptide. Injections were performed every 2 weeks with $20 \mu \mathrm{g}$ of
KLH-peptides emulsified in complete Freund adjuvant (first injection) or incomplete Freund adjuvant (following injections). The 2 first injections were performed via intraperitoneal route and the following injections via subcutaneous route. After the 5th injection, blood was collected in order to characterize the immune response to full-length adiponectin. The study was approved by the "direction départementale de la protection des populations" (B34-172-27 agreement).

Immune response characterization Binding activity of the immune serum to recombinant adiponectin and irrelevant protein was evaluated by direct ELISA. The plates were coated overnight at $4{ }^{\circ} \mathrm{C}$ with $1 \mu \mathrm{g} / \mathrm{ml}$ of recombinant trimeric form of human adiponectin produced in HEK cells (BioVendor, \#RD172091100) or purified Human Serum Albumin (HSA) (Sigma-Aldrich, A9511). After blocking with $1 \%$ milk in PBS, mouse serum was diluted from $1 / 1000$ to $1 / 100000$ in PBS with $0.1 \%$ milk and $0.1 \%$ Tween and plates were incubated for $1 \mathrm{~h}$. After washing, the secondary Ab PeroxidaseAffiniPure Donkey Anti-Mouse IgG (Jackson Immuniresearch, 715-035-150) was incubated for $1 \mathrm{~h}$ at 1/3000 in the same buffer followed by o-Phenylenediamine dihydrochloride (Sigma Aldrich, P8412). The absorbance was measured at $490 \mathrm{~nm}$.

\section{Plasma reactivity with the discontinuous peptides from coagulation FVIII}

The ability of peptides to inhibit the binding of anti-C2 Abs to the $\mathrm{C} 2$ domain was then evaluated in an original and homemade inhibition assay. Briefly, the domain of interest was immobilized on luminex beads. The plasma of hemophilia A (HA) patients containing anti-C2 Abs was incubated with a range of concentrations of peptides and thereafter incubated with beads. The dosedependent inhibition of peptides was revealed with a fluorescent anti-human $\mathrm{Ab}$, recognizing residual plasma Abs bound to the specific domain coated on beads. If the predicted peptide mimicked one of the epitopes recognized by human anti-C2 Abs, the level of fluorescence decreased and the inhibition rate increased. This study was connected to Lapalud et al. study [77] for which the protocol was approved by the Ethics Committee of Montpellier (France), and informed consent was obtained for all patients in accordance with the Declaration of Helsinki.

\section{Additional files}

Additional file 1: Sup data 1. Description of the NP-problem when predicting a peptide expected to mimic a discontinuous epitope (PDF $36 \mathrm{~kb}$ )

Additional file 2: Table S1. Comparison of 75 known epitopes with PEPOP predictions. (XLSX $12 \mathrm{~kb}$ ) 


\section{Abbreviations}

aa: Amino acids; Ab: Antibody; Ag: Antigen; FVIII: Factor VIII; HA: Hemophilia A
Received: 5 November 2018 Accepted: 30 April 2019

Published online: 11 July 2019

\section{Acknowledgements}

We warmly thank Dr. P. Lapalud for her collaboration, D. Jean for his precious technical contribution, and Dr. P. Voyvodic and Dr. A. Nord for English language editing and review. We are grateful to A.-M. Madec and M. Powell for providing anti-GAD65 DPC and mAb54 monoclonal antibodies.

\section{Funding}

This work was supported by grants from the Ministry of Research (France); University Paris Diderot, Sorbonne Paris Cité (France); the National Institute for Blood Transfusion (INTS, France); the Brazilian institutions CAPES, FAPEMIG and CNPQ; the Institute for Health and Medical Research (INSERM, France); and a Labex GR-Ex grant (France) to Alexandre G. de Brevern. The Labex GR-Ex, reference ANR-11-LABX-0051, is funded by the program "Investissements d'avenir" of the French National Research Agency, reference ANR-11IDEX-0005-02. The funding body had no role in the design and collection of the study, experiments, analyses and interpretations of data, and in writing the manuscript.

\section{Availability of data and materials}

All data generated or analyzed during this study are included in this published article and its additional files.

\section{Authors' contributions}

VM supervised the project. VM, VD, AdB and FM developed the tool and its web site. VM, LF, CNG, RAMA, LV, BJW, GL and AL participated to experimental validation (acquisition of data, analyzes and interpretations). The manuscript was first drafted by VM, revised by AdB and approved by all authors.

\section{Ethics approval and consent to participate}

Concerning the mouse immunization, the study was approved by the "direction départementale de la protection des populations" (B34-172-27 agreement).

Concerning the plasma reactivity, the study was connected to Lapalud et al. study [77] for which the protocol was approved by the Ethics Committee of Montpellier (France), and oral consent was obtained for all patients in accordance with the Declaration of Helsinki.

\section{Consent for publication}

Not applicable in this section.

\section{Competing interests}

The authors declare that they have no competing interests.

\section{Publisher's Note}

Springer Nature remains neutral with regard to jurisdictional claims in published maps and institutional affiliations.

\section{Author details}

'BPMP, CNRS, INRA, Montpellier SupAgro, Univ Montpellier, Montpellier, France. ${ }^{2}$ INSERM UMR-S 1134, DSIMB, F-75739 Paris, France. ${ }^{3}$ Univ Paris Diderot, Sorbonne Paris Cité, Univ de la Réunion, Univ des Antilles, UMR 1134, F-75739 Paris, France. ${ }^{4}$ INTS, F-75739 Paris, France. ${ }^{5}$ Laboratoire d'Excellence GR-Ex, F75737 Paris, France. ${ }^{6}$ Departamento de Bioquímica e Imunologia, Universidade Federal de Minas Gerais, Belo Horizonte, MG, Brazil. ${ }^{7}$ Sys2Diag UMR 9005 CNRS/ALCEDIAG, Complex System Modeling and Engineering for Diagnosis, Cap delta/Parc Euromédecine, 1682 rue de la Valsière CS 61003, 34184 Montpellier Cedex 4, France. ${ }^{8}$ Programa de Pós-Graduação em Ciências da Saúde, Universidade do Extremo Sul Catarinense, Criciúma, Santa Catarina 88806-000, Brazil. ' Bio-Rad Laboratories, 1682 Rue de la Valsière CS 61003, 34184 Montpellier CEDEX 04, France. ${ }^{10}$ Department of Haematology, University Hospital, Nîmes, France. ${ }^{11}$ Service d'hématologie biologique, CHU Clermont-Ferrand, Clermont-Ferrand, France. ${ }^{12}$ Centre de Biochimie Structurale (CBS), INSERM, CNRS, Univ Montpellier, 29, route de Navacelles, 34090 Montpellier, France.

\section{References}

1. Bijker MS, Melief CJ, Offringa R, van der Burg SH. Design and development of synthetic peptide vaccines: past, present and future. Expert Rev Vaccines. 2007:6:591-603.

2. Gomara MJ, Haro I. Synthetic peptides for the immunodiagnosis of human diseases. Curr Med Chem. 2007;14:531-46.

3. Van Regenmortel MH. From absolute to exquisite specificity. Reflections on the fuzzy nature of species, specificity and antigenic sites. J Immunol Methods. 1998;216:37-48.

4. Atassi MZ, Smith JA. A proposal for the nomenclature of antigenic sites in peptides and proteins. Immunochemistry. 1978;15:609-10.

5. Benjamin DC. B-cell epitopes: fact and fiction. Adv Exp Med Biol. 1995;386: 95-108.

6. Van Regenmortel MH. Antigenicity and immunogenicity of synthetic peptides. Biologicals. 2001;29:209-13.

7. Sun P, Ju H, Liu Z, Ning Q, Zhang J, Zhao X, et al. Bioinformatics resources and tools for conformational B-cell epitope prediction. Comput Math Methods Med. 2013;2013:1-11.

8. El-Manzalawy Y, Honavar V. Recent advances in B-cell epitope prediction methods. Immunome Res. 2010;6(Suppl 2):S2.

9. Gershoni JM, Roitburd-Berman A, Siman-Tov DD, Tarnovitski Freund N Weiss Y. Epitope mapping: the first step in developing epitope-based vaccines. BioDrugs. 2007:21:145-56.

10. Reineke U, Schutkowski M. Epitope mapping protocols. Preface. Methods Mol Biol. 2009;524:v-vi.

11. Pellequer $J$, Westhof $E$, Van Regenmortel MH. Epitope prediction from primary structure of proteins. In: Wisdow GB, editor. Peptide antigens: a practical approach. Oxford: IRL Press; 1994. p. 7-25.

12. Hopp TP, Woods KR. Prediction of protein antigenic determinants from amino acid sequences. Proc Natl Acad Sci U S A. 1981;78:3824-8.

13. Karplus PA, Schulz GE. Prediction of chain flexibility in proteins. Naturwiss. 1985;72:212-3.

14. Pellequer JL, Westhof E, Van Regenmortel MH. Correlation between the location of antigenic sites and the prediction of turns in proteins. Immunol Lett. 1993;36:83-99.

15. Lee B, Richards FM. The interpretation of protein structures: estimation of static accessibility. J Mol Biol. 1971;55:379-400.

16. Welling GW, Weijer WJ, van der Zee $\mathrm{R}$, Welling-Wester S. Prediction of sequential antigenic regions in proteins. FEBS Lett. 1985;188:215-8.

17. Sweredoski MJ, Baldi P. COBEpro: a novel system for predicting continuous B-cell epitopes. Protein Eng Des Sel. 2009;22:113-20.

18. Wang HW, Lin YC, Pai TW, Chang HT. Prediction of B-cell linear epitopes with a combination of support vector machine classification and amino acid propensity identification. J Biomed Biotechnol. 2011;2011:432830.

19. Alix AJ. Predictive estimation of protein linear epitopes by using the program PEOPLE. Vaccine. 1999;18:311-4.

20. Blythe MJ, Flower DR. Benchmarking B cell epitope prediction: underperformance of existing methods. Protein Sci. 2005;14:246-8.

21. Barlow DJ, Edwards MS, Thornton JM. Continuous and discontinuous protein antigenic determinants. Nature. 1986;322:747-8.

22. Ito HO, Nakashima T, So T, Hirata M, Inoue M. Immunodominance of conformation-dependent B-cell epitopes of protein antigens. Biochem Biophys Res Commun. 2003;308:770-6.

23. Kulkarni-Kale U, Bhosle S, Kolaskar AS. CEP: a conformational epitope prediction server. Nucleic Acids Res. 2005;33:W168-71.

24. Batori V, Friis EP, Nielsen H, Roggen EL. An in silico method using an epitope motif database for predicting the location of antigenic determinants on proteins in a structural context. J Mol Recognit. 2006;19: 21-9.

25. Haste Andersen $P$, Nielsen $M$, Lund $O$. Prediction of residues in discontinuous B-cell epitopes using protein 3D structures. Protein Sci. 2006; 15:2558-67.

26. Potocnakova L, Bhide M, Pulzova LB. An introduction to B-cell epitope mapping and in silico epitope prediction. J Immunol Res. 2016;2016:1-11.

27. Zhang $W$, Xiong $Y$, Zhao M, Zou H, Ye X, Liu J. Prediction of conformational B-cell epitopes from 3D structures by random forests with a distance-based feature. BMC Bioinformatics. 2011;12:341. 
28. Sweredoski MJ, Baldi P. PEPITO: improved discontinuous B-cell epitope prediction using multiple distance thresholds and half sphere exposure. Bioinformatics. 2008;24:1459-60.

29. Rubinstein ND, Mayrose I, Pupko T. A machine-learning approach for predicting B-cell epitopes. Mol Immunol. 2009;46:840-7.

30. Ponten F, Schwenk JM, Asplund A, Edqvist PH. The human protein atlas as a proteomic resource for biomarker discovery. J Intern Med. 2011;270:428-46.

31. Stastna M, Van Eyk JE. Secreted proteins as a fundamental source for biomarker discovery. Proteomics. 2012;12:722-35.

32. Casey JL, Coley AM, Parisi K, Foley M. Peptide mimics selected from immune sera using phage display technology can replace native antigens in the diagnosis of Epstein-Barr virus infection. Protein Eng Des Sel. 2009;22:85-91.

33. Goede A, Jaeger IS, Preissner R. SUPERFICIAL--surface mapping of proteins via structure-based peptide library design. BMC Bioinformatics. 2005;6:223

34. Moreau V, Fleury C, Piquer D, Nguyen C, Novali N, Villard S, et al. PEPOP: computational design of immunogenic peptides. BMC Bioinformatics. 2008;9:71.

35. Alvarenga L, Moreau V, Felicori L, Nguyen C, Duarte C, Chavez-Olortegui C, et al. Design of antibody-reactive peptides from discontinuous parts of scorpion toxins. Vaccine. 2010;28:970-80.

36. Ponomarenko JV, Bourne PE. Antibody-protein interactions: benchmark datasets and prediction tools evaluation. BMC Struct Biol. 2007;7:64.

37. Reineke U, Kramer A, Schneider-Mergener J. Antigen sequence- and librarybased mapping of linear and discontinuous protein-protein-interaction sites by spot synthesis. Curr Top Microbiol Immunol. 1999;243:23-36.

38. Frank R. The SPOT-synthesis technique. Synthetic peptide arrays on membrane supports--principles and applications. J Immunol Methods. 2002; 267:13-26.

39. Alvarenga LM, Martins MS, Moura JF, Kalapothakis E, Oliveira JC, Mangili OC, et al. Production of monoclonal antibodies capable of neutralizing dermonecrotic activity of Loxosceles intermedia spider venom and their use in a specific immunometric assay. Toxicon. 2003:42:725-31.

40. Felicori L, Araujo S, de Avila R, Sanchez E, Granier C, Kalapothakis E, et al. Functional characterization and epitope analysis of a recombinant dermonecrotic protein from Loxosceles intermedia spider. Toxicon. 2006;48: 509-19.

41. de Moura J, Felicori L, Moreau V, Guimarães G, Dias-Lopes C, Molina L, et al. Protection against the toxic effects of Loxosceles intermedia spider venom elicited by mimotope peptides. Vaccine. 2011;29:7992-8001.

42. Lebreton A, Moreau V, Lapalud P, Cayzac C, André S, Nguyen C, et al. Discontinuous epitopes on the C2 domain of coagulation factor VIII mapped by computer-designed synthetic peptides. Br J Haematol. 2011;155:487-97.

43. Lebreton A, Simon N, Moreau V, Demolombe V, Cayzac C, Nguyen C, et al. Computer-predicted peptides that mimic discontinuous epitopes on the A2 domain of factor VIII. Haemophilia. 2015;21:e193-201.

44. De-Simone S, Napoleão-Pêgo P, De-Simone T. Spot synthesis: an optimized microarray to detect lgE epitopes. Methods Mol Biol. 2016;1352:263-77.

45. Lima S, Guerra-Duarte C, Costal-Oliveira F, Mendes T, Figueiredo L, Oliveira D, et al. Recombinant protein containing B-cell epitopes of different Loxosceles spider toxins generates neutralizing antibodies in immunized rabbits. Front Immunol. 2018;9:653.

46. Andresen $H$, Bier FF. Peptide microarrays for serum antibody diagnostics. Methods Mol Biol. 2009;509:123-34.

47. Benjamin DC, Berzofsky JA, East IJ, Gurd FR, Hannum C, Leach SJ, et al. The antigenic structure of proteins: a reappraisal. Annu Rev Immunol. 1984;2:67-101.

48. Lollier $\mathrm{V}$, Denery-Papini S, Larre C, Tessier D. A generic approach to evaluate how B-cell epitopes are surface-exposed on protein structures. Mol Immunol. 2011:48:577-85.

49. Murphy K. Janeway's Immunobiology. In: Science G, editor. Janeway's Immunobiology. 8th ed; 2012. p. 611-68.

50. Bachmann MF, Jennings GT. Vaccine delivery : a matter of size, geometry, kinetics and molecular patterns. Nat Publ Gr Nature Publishing Group. 2010; 10:787-96.

51. Yin $L$, Chen $X$, Tiwari A, Vicini $P$, Hickling $T$. The role of aggregates of therapeutic protein products in immunogenicity: an evaluation by mathematical modeling. J Immunol Res. 2015;2015:1-14.

52. Nilvebrant J, Tessier PM, Sidhu SS, Studies I, Engineering B. Engineered autonomous human variable domains. Curr Pharm Des. 2016;22:6527-37.

53. Ait Mebarek M, Wijkhuisen A, Adel-patient K, Lamourette $P$, Léonetti M, Volland $\mathrm{H}$. Production of human antibodies by in vitro immunization using a fusion protein containing the transcriptional transactivator of HIV-1. J Immunol Methods Elsevier BV. 2013:396:96-106.

54. de Almeida R, Nakamura C, Fontes de Lima M, Deffune E, Felisbino S, Kaneno $\mathrm{R}$, et al. Enhanced immunization techniques to obtain highly speci fi c monoclonal antibodies. MAbs. 2018;10:46-54.

55. Miersch S, Sidhu S. Synthetic antibodies: concepts, potential and practical considerations. Methods. 2012;57:486-98.

56. Fischman S, Ofran Y. Computational design of antibodies. Curr Opin Struct Biol Elsevier Ltd. 2018;51:156-62.

57. Hopp TP. Protein surface analysis. Methods for identifying antigenic determinants and other interaction sites. J Immunol Methods. 1986:88:1-18.

58. Ambroise J, Giard J, Gala J, Macq B. Identification of relevant properties for epitopes detection using a regression model. IEEE/ACM Trans Comput Biol Bioinform. 2011:8:1700-7.

59. Rahman K, Chowdhury E, Sachse K, Kaltenboeck B. Inadequate reference datasets biased toward short non-epitopes confound B-cell epitope prediction * ${ }^{*}$. J Biol Chem. 2016;291:14585-99.

60. Berzofsky JA. Intrinsic and extrinsic factors in protein antigenic structure. Science (80- ). 1985:229:932-40.

61. Dangi AK, Sinha R, Dwivedi S, Gupta SK. Cell line techniques and gene editing tools for antibody production : a review. Front Pharmacol. 2018;9:1-12.

62. Van Regenmortel MH. Reductionism and complexity in molecular biology. Scientists now have the tools to unravel biological and overcome the limitations of reductionism. EMBO Rep. 2004;5:1016-20.

63. Jones S, Thornton JM. Principles of protein-protein interactions. Proc Natl Acad Sci U S A. 1996:93:13-20.

64. Lo Conte L, Chothia C, Janin J. The atomic structure of protein-protein recognition sites. J Mol Biol. 1999;285:2177-98.

65. Chen SW, Van Regenmortel MH, Pellequer JL. Structure-activity relationships in peptide-antibody complexes: implications for epitope prediction and development of synthetic peptide vaccines. Curr Med Chem. 2009;16:953-64.

66. Ramaraj T, Angel T, Dratz EA, Jesaitis A, Mumey B. Antigen-antibody interface properties: composition, residue interactions, and features of 53 non-redundant structures. Biochim Biophys Acta. 2012;1824:520-32.

67. Irving MB, Craig L, Menendez A, Gangadhar BP, Montero M, van Houten NE, et al. Exploring peptide mimics for the production of antibodies against discontinuous protein epitopes. Mol Immunol. 2010;47:1137-48.

68. Bogan AA, Thorn KS. Anatomy of hot spots in protein interfaces. J Mol Biol. 1998;280:1-9.

69. Chakrabarti P, Janin J. Dissecting protein-protein recognition sites. Proteins. 2002:47:334-43.

70. Yan C, Wu F, Jernigan RL, Dobbs D, Honavar V. Characterization of proteinprotein interfaces. Protein J. 2008;27:59-70.

71. Goh CS, Milburn D, Gerstein M. Conformational changes associated with protein-protein interactions. Curr Opin Struct Biol. 2004;14:104-9.

72. Greenbaum JA, Haste Andersen P, Blythe M, Bui HH, Cachau RE, Crowe J, et al. Towards a consensus on datasets and evaluation metrics for developing B-cell epitope prediction tools. J Mol Recognit. 2007;20:75-82.

73. Frank R. Spot-synthesis: an easy technique for the positionally addressable, parallel chemical synthesis on a membrane support. Tetrahedron. 1992;48: 9217-32.

74. Laune D, Molina F, Ferrieres G, Villard S, Bes C, Rieunier F, et al. Application of the spot method to the identification of peptides and amino acids from the antibody paratope that contribute to antigen binding. J Immunol Methods. 2002;267:53-70.

75. Gausepohl H, Boulin C, Kraft M, Frank RW. Automated multiple peptide synthesis. Pept Res. 1992;5:315-20.

76. Fields GB, Noble RL. Solid phase peptide synthesis utilizing 9fluorenylmethoxycarbonyl amino acids. Int J Pept Protein Res. 1990;35: 161-214.

77. Lapalud P, Rothschild C, Mathieu-Dupas E, Balicchi J, Gruel Y, Laune D, et al. Anti-A2 and anti-A1 domain antibodies are potential predictors of immune tolerance induction outcome in children with hemophilia a. J Thromb Haemost. 2015;13:540-7. 